TITLE:

Pore throat size and connectivity determine bone and tissue ingrowth into porous implants : three-dimensional micro-CT based structural analyses of porous bioactive titanium implants(Abstract_要旨)

\title{
$\operatorname{AUTHOR}(\mathrm{S}):$
}

\section{Otsuki, Bungo}

\section{CITATION:}

Otsuki, Bungo. Pore throat size and connectivity determine bone and tissue ingrowth into porous implants : threedimensional micro-CT based structural analyses of porous bioactive titanium implants. 京都大学, 2007, 博士(医学)

\section{ISSUE DATE:}

2007-03-23

URL:

http://hdl.handle.net/2433/135706

\section{RIGHT:}




\begin{tabular}{|c|c|}
\hline 氏 & 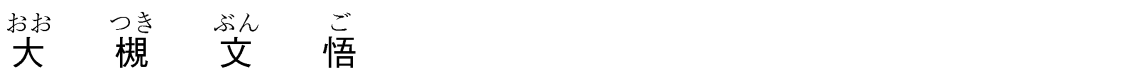 \\
\hline 学位(専攻分野) & 士（医 \\
\hline 学 位 記 番 号 & 医 博 第 3086 号 \\
\hline 学位授与の日付 & 平成 19 年 3 月 23 日 \\
\hline 学位授与の要件 & 学 位規則第 4 条第 1 項該当 \\
\hline 研究科・専攻 & 医学研究科外科系専攻 \\
\hline 学位論文題目 & $\begin{array}{l}\text { Pore throat size and connectivity determine bone and tissue ingrowth } \\
\text { into porous implants: Three-dimensional micro-CT based structural } \\
\text { analyses of porous bioactive titanium implants } \\
\text { (ポーラス体への骨組織侵入は連通孔のサイズと連通性が規定する：生体活 } \\
\text { 性ポーラスチタン材料のマイクロ CTを用いた } 3 \text { 次元構造解析） }\end{array}$ \\
\hline 文調査 & 教 授 別 所 和 久 \\
\hline
\end{tabular}

\section{論 文 内 容 の 要旨}

ポーラス構造を有する材料は，組織侵入が可能であることから，様々な分野で応用されている。特に骨内で用いるインプ ラントにおいて, 骨侵入の程度は, 組織と材料間の接着強度と密接に相関する。これまで, 連通距離が長いほど骨侵入が遅 延することが示されており, さらに平均気孔径と骨侵入の程度については数多く発表されている。しかし, ポーラス体は複 雑な 3 次元構造を有し, 骨侵入を規定する因子として連通距離以外の明確な因子は明らでない。今回我々は, 連通距離以外 に，連通のサイズが骨侵入に影響し，それが小さいことで骨侵入が阻害されるいう仮説をたて検証した。

材料は，良好な組織親和性を有し，平均気孔径や気孔率を調節できるチタン製インプラントを用い，日本白色家鬼の大腿 骨顆部に埋入して骨侵入を検証した。予備実験として，4 種類の異なった気孔率と気孔径のインプラントを使用し，埋入後 6，12週で摘出し組織評価を行ったところ，ST50-250（目標気孔率50\%，気孔形成剤の径が 250-500 $\mathrm{mm}$ ）というインプラ ントが最も骨侵入が劣っており，各気孔によって骨侵入の程度が様々であった。さらに隣り合う気孔でも骨侵入の程度が異 なるものが多く見られた。そこで今回の実験ではこの ST50-250を用い解析した。まずインプラントを $\mu \mathrm{CT}$ にて撮像し， その後, 家兔に埋入した。6週で摘出後, 組織切片を 3 枚作製し, それぞれの切片のすべての気孔の骨侵入の程度を組織学 的に 5 段階で評価した。さらに隣り合う気孔で, 骨侵入の程度が異なるぺアを 40 組抽出し, それぞれのペアの骨侵入が良好 な気孔群を分化良好群，覀い方の気孔群を分化不良群とした。分化良好群，分化不良群の各ポアに対し，事前に撮像した $\mu \mathrm{CT}$ のデー夕を用い, 連通の 3 次元構造を解析した。3 次元構造の指標として, それぞれの気孔までの最短連通距離 (SDI)，材料周囲からの最短距離（DP），SDI $\mathrm{DP}$ で除したDetour Index（DI=SDI/DP）の3つを用い，さらに特定 のサイズ以下の連通をブロックすることでこの 3 つの指標がどのように変化するかを検証した。また特定のサイズ以下の連 通をブロックすることで連通を失う dead pore の数も検証した。これらの解析は独自のソフトウエアを作製して行った。

分化良好群と分化不良群は連通をブロックしない状態で平均 SDI に有意な差を認めず，このことは 2 群の骨侵入の違い が, 最短連通距離に依らないことを示している。そこで連通のサイズが $26,52,78 \mu \mathrm{m}$ 以下であるものを順に遮断していく ことで, dead poreの割合に差があるかを検証した。その結果，分化良好群ではより大きなサイズの連通をブロックしない と dead poreになりにくく，また分化不良群ではより小さいサイズの連通をブロックすることで dead poreになりやすいこ とが示された。つぎに dead pore を含まないペアを抽出し，DI の值の比較を行った。同様に各サイズの連通をブロックし ていくと，そのサイズが大きくなるにつれて，分化不良群のDI 值が分化良好群と比較して有意に高くなることが示された。 この結果は, 骨侵入に重要と考えられる, 距離が短い連通群の内部に狭い連通が有意に多く存在していることを示している。 以上の結果から，連通径が骨侵入を規定する重要な因子であり，狭い連通が骨侵入を阻害することが示された。さらに我々 は上記の結果を基に材料全体の骨侵入を予測する 2 つの指標を提案し，それらの指標が実際の骨侵入と非常に良く相関する ことを示した。 
今後，他の材料や他の動物種においても応用が可能であると考えられた。

\section{論 文審査の結果の要旨}

ポーラス構造を有する生体材料は様々な手術に広く用いられており，今後もその応用が期待される。特に骨組織に用いる 材料は骨侵入が起こることで機械的結合を獲得することができるため，良好な骨侵入が不可欠である。ポーラス体は複雑な 3 次元構造を有するが, どのような構造のポーラス体が骨組織と良好な親和性を有するかは解明されていない。本研究では, アルカリ処理を用いた生体活性ポーラスチタンを用い，その３次元構造をマイクロCTを用いて解析し，さらにその結果と 動物実験を用いた骨侵入の組織学的結果とを対応させることで，3 次元構造が骨侵入に及ぼす影響について検討した。

骨侵入はこれまでに解明されてきたように，連通に沿って進行し，徐々に組織学的に成熟することが分かった。さらにこ の成熟の速度が，連通径の最も狭い部分の径に大きく影響を受けることが明らかとなった。特に連通径 $50 \mu \mathrm{m}$ 程度以下の連 通は，大きく骨侵入やその成熟を阻害していた。またこれらの結果から，ポーラス生体材料の 3 次元連通性を示す指標を考 案し動物実験の結果と比較したところ，非常に高い相関を示した。

以上の研究は, ポーラス生体材料, 特にポーラスチタン材料における 3 次元構造が骨侵入に重要であることを明らかにし, 連通路の径が骨侵入に影響することを初めて示したものである。この結果を応用することでポーラス生体材料の開発に大き く貢献するものと考えられる。

したがって, 本論文は博士 (医学) の学位論文として価値あるものと認める。

なお，本学位授与申請者は，平成19年 2 月 9 日実施の論文内容とそれに関した試問を受け，合格と認められたものである。 